\title{
Sistem Perpustakaan Digital dan Administrasi Perpustakaan Dalam Meningkatkan Pelayanan Perpustakaan
}

\author{
Cahya Vikasari* \\ Program Studi Teknik Informatika, Politeknik Negeri Cilacap \\ Jl. Dr. Soetomo No.1 Sidakaya Cilacap, Indonesia \\ E-mail: cahyavikasari@pnc.ac.id
}

Info Naskah:

Naskah masuk: 4 November 2020

Direvisi: 14 Maret 2021

Diterima:20 Agustus 2021

\begin{abstract}
Abstrak
Kegiatan yang ada di perpustakaan yaitu kegiatan administrasi, peminjaman dan pengembalian buku, peminjaman buku referensi tugas akhir dan magang industri masih terdapat kendala antara lain banyak kegiatan yang dilakukan secara manual dan jumlah staf yang sedikit sehingga akan menghambat proses administrasi dan pelayanan perpustakaan. Proses pencarian referensi akan kesulitan oleh pemustaka dan dengan adanya kondisi pandemik covid-19 maka diberlakukan work from home hal ini juga akan berdampak pada administrasi dan pelayanan di perpustakaan. Pembangunan sistem digitalisasi dan administrasi perpustakaan dalam meningkatkan pelayanan perpustakaan PNC dengan metode pengembangan perangkat lunak systems development life cycle dan sistem dibangun berbasis web. Perancangan menggunakan konsep UML, Pengujian sistem dengan menggunakan blackbox testing metode boundary value analysis serta evaluasi system dengan konsep end user computing satisfaction. Tujuan dari penelitian ini yaitu membangun sistem digitalisasi perpustakaan dan otomatisasi perpustakaan yang dapat membantu proses administrasi dan pelayanan terhadap pemustaka. Hasil dari penelitian adalah sistem digitalisasi yang yang dapat memberikan informasi yaitu referensi berupa buku tugas akhir dan magang industri di perpustakaan berbasis web dan sistem sirkulasi mandiri di perpustakaan yang akan mendukung layanan perpustakaan lebih efektif dan efisien.
\end{abstract}

\section{Keywords:}

automation;

digitization;

reference.

\begin{abstract}
Activities in the library The process of finding references will be difficult for users and with the Covid-19 pandemic condition, work from home is enforced, this will also have an impact on administration and services in the library. Development of a digitalization system and library administration in improving the services of the PNC library using the software development method of the system development life cycle and the system built on a web-based basis. The design uses the UML concept, system testing using the blackbox testing method, boundary value analysis, and system evaluation with the concept of end-user computing satisfaction. The purpose of this research is to build a library digitalization system and library automation that can assist the administrative process and service to users. The result of the research is a digitalization system that can provide information, namely references in the form of final project books and industrial internships in web-based libraries and independent circulation systems in libraries that will support library services more effectively and efficiently.
\end{abstract}

\begin{tabular}{l}
\hline *Penulis korespondensi: \\
Cahya Vikasari \\
E-mail: cahyavikasari@pnc.ac.id \\
\hline \hline
\end{tabular}




\section{Pendahuluan}

Unit pelaksana teknis perpustakaan sebagai pendukung kegiatan belajar mengajar yang ada di Politeknik Negeri Cilacap secara tidak langsung memiliki peranan yang sangat penting. Kualitas sebuah layanan pada perpustakaan merupakan standar dari sebuah proses yang harus dilaksanakan dalam layanan perpustakaan dalam memenuhi harapan serta tuntutan dari pengguna[1]. pelayanan yang dilakukan perpustakaan harus secara prima serta berorientasi bagi kepentingan pengguna yaitu mahasiswa atau pemustaka[2]. Peran penting perpustakaan dalam dunia pendidikan antara lain sebagai pendidik dan kolaborator , administrator program, navigator, evaluator, dan penerbit[3]. Perpustakaan perguruan tinggi di Politeknik Negeri Cilacap merupakan jantung dari perguruan tinggi (the hearth of university). Fungsi dari perpustakaan sebagai wahana rekreasi dalam meningkatkan kecerdasan dan keberdayaan suatu bangsa, perpustakaan juga memiliki fungsi dalam menunjang pendidikan bagi pemustakanya [4]. Fungsi lain dari perpustakaan didalam sebuah lingkungan perguruan tinggi itu sendiri yaitu sebagai pusat dari kegiatan belajar mengajar, pusat dari penelitian yang dilaksanakan oleh dosen ataupun mahasiswa dan pusat informasi bagi pelaksana Tri Dharma Perguruan Tinggi

Beberapa kegiatan yang ada di perpustakaan yaitu kegiatan administrasi yang dilakukan oleh staff perpustakaan misalnya data mou kerjasama, saran dari pemustaka, kegiatan upt perpustakaan, surat bebas pustaka mengelola data tugas akhir dan magang industry serta peminjaman dan pengembalian buku, peminjaman buku referensi tugas akhir dan magang industri. Kondisi saat ini jumlah pegawai yang ada di perpustakaan berjumlah 4 orang dengan job depkripsi masing-masing dan penambahan jurusan di politeknik negeri cilacap akan berimbas pada bertambahnya jumlah mahasiswa sehingga jumlah staff diperpustakaan dan jumlah mahasiswa yang bertambah akan membuat kesulitan untuk melaksanakan pelayanan yang optimal.

Kendala lain di UPT Perpustakaan PNC yaitu dalam kegiatan administrasi masih banyak kegiatan yang dilakukan secara manual, misalnya untuk membuat kartu anggota baru, pegawai perpustakaan harus mengedarkan formulir untuk mendapatkan data dan kemudian data tersebut akan diproses satu persatu oleh pegawai, memasukan data magang industri dan tugas akhir dilakukan setelah mahasiswa mengumpulkan buku tugas akhir maka pegawai juga akan memasukan data satu per satu tersebut, dalam hal peminjaman dan pengembalian buku mahasiswa harus mengantri agar peminjaman dan pengembalian bukunya dapat di proses oleh staff perpustakaan. Kegiatan peminjaman buku tugas akhir ataupun magang industri juga mengalami kendala, yaitu buku yang ada hanya 1 buah, jika ada mahasiswa yang meminjamnya maka mahasiswa lainnya harus menunggu sampai peminjam sebelumnya selesai meminjam hal ini akan mengakibatkan mahasiswa keulitan dalam mendapatkan referensi yang dibutuhkan, buku referensi tugas akhir ini juga rentan hilang.

Dampak dari pandemik Covid-19 akan mempengaruhi psikologis dan perilaku manusia. Hal ini berdampak pada sistem pendidikan di Indonesia. Pengajar dan peserta didik akan terbiasa melakukan interaksi pembelajaran jarak jauh atau daring[5]. Pembelajaran daring membutuhkan jaringan internet dengan konektivitas, aksesibilitas, fleksibilitas, dan memiliki kemampuan untuk dapat memunculkan berbagai jenis interaksi pembelajaran[6]. Pandemik virus covid-19 juga telah mempengaruhi fasilitas pendukung Pendidikan perguruan tinggi misalnya UPT Perpustakaan.

Beberapa permasalahan yang aada yaitu pemustaka kesulitan dalam mencari referensi dan membaca referensi tersebut di perpustakaan karena Politeknik Negeri Cilacap menerapkan konsep kerja work from home (WFH) sehingga akan mempengaruhi proses tugas akhirnya karena harus berdasarkan referensi. Hal ini membuat kesulitan mahasiswa yang akan mencari referensi untuk tugas akhirnya karena perpustakaan PNC dalam pandemik virus covid-19 ditutup, dan mahasiswa tidak mendapatkan referensi dari perpustakaan. Dukungan dari perpustakaan sangat diperlukan untuk mendukung mahasiswa yang sedang mengerjakan tugas akhirnya.

Tutupnya perpustakaan sehingga mahasiswa tidak mendapat referensi dan aktifitas yang begitu banyak untuk menyelesaikan administrasi dan pelayanan yang dilakukan oleh pegawai perpustakaan akan menimbulkan kerumitan dan kendala karena data yang ada harus diolah terlebih dahulu oleh staff perpustakaan dengan konsep WFH dan tutupnya perpustakaan. Kebutuhan referensi oleh pemustaka dirasa perlu adanya perpustakaan digital yang dapat mendukung di era pandemi covid-19 sehingga dapat memperkaya referensi tugas akhir yang sedang dikerjakannya. Otomatisasi kegiatan misal pengumpulan data tugas akhir, data magang, data pengembalian dan peminjaman buku pengajuan surat bebas pustaka dapat dilakukan secara mandiri melalui aplikasi oleh mahasiswa sehingga pustakawan dapat memproses data penting lainnya yang mendukung perpustakaan terkait dengan jumlah staff perpustakaan terbatas. Diperlukan adanya sistem untuk meminimalisasi masalah diatas, diantaranya dengan membangun sistem perpustakaan digital dan administrasi perpustakaan Politeknik Negeri Cilacap, yang dapat memberikan informasi terhadap referensi-referensi yang diperlukan oleh pemustaka di perpustakaan berbasis web yang dapat diakses tanpa harus ke perpustakaan PNC dan administrasi di perpustakaan lebih efektif dan efisien dan dapat digunakan dalam kondisi pandemik.

Tujuan dari penelitian ini yaitu membangun sistem digitalisasi perpustakaan untuk referensi buku tugas akhir dan buku magang industry, layanan sirkulasi mandiri yang dapat mempermudah dalam peminjaman dan pengembalian buku secara mandiri serta mempermudah administrasi perpustakaan PNC.

\section{Metodologi Penelitian \\ 2.1 Bahan Penelitian}

Bahan penelitian diperoleh dari proses observasi lapangan pada perpustakaan dan proses wawancara dengan petugas perpustakaan. Studi literatur juga dilakukan untuk mendapatkan informasi mengenai penelitia-penelitian sebelumnya. Bahan penelitian yang digunakan dalam kegiatan penelitian dapat dilihat pada Tabel 1. 
Tabel 1. Bahan Penelitian

\begin{tabular}{ll}
\hline \multicolumn{1}{c}{ Data } & \multicolumn{2}{c}{ Tujuan } \\
\hline Proses bisnis dalam proses & Mengetahui alur kerja dalam \\
administrasi perpustakaan & administrasi perpustakaan \\
Data literatur penelitian & Mengetahui a aktivitas \\
sebelumnya mengenai & penelitian yang dilakukan \\
virtual workplace & sebelumnya, sehingga dapat \\
& dilakukan perbaikan pada \\
& penelitian ini. \\
\hline
\end{tabular}

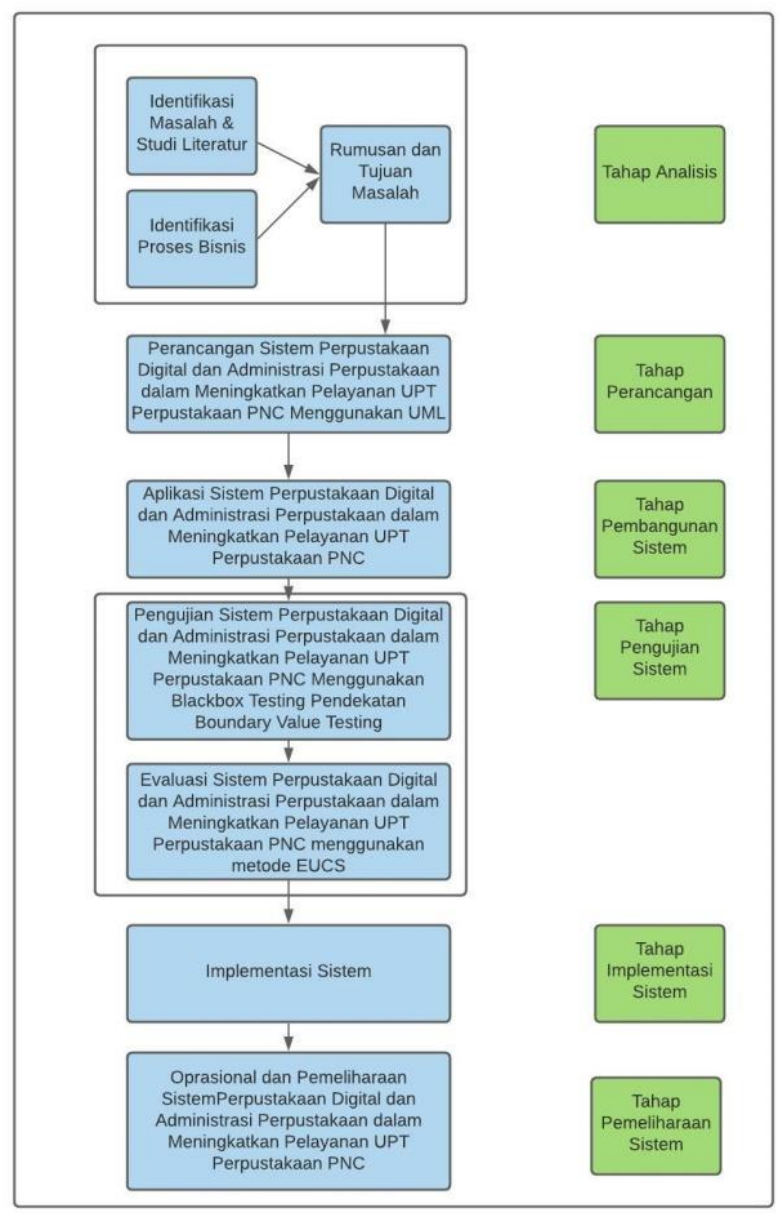

Gambar 1. Tahapan Penelitian

\subsection{Metode Pengembangan Sistem}

Tahapan penelitian yang dilakukan dalam membangun sistem digitalisasi dan otomatisasi perpustakaan yaitu menggunakan metode Systems development life cycle merupakan proses pengembangan perangkat lunak dengan metodologi yang digunakan untuk mengambangkan perangkat lunak beradasarkan best practice[7]. SDLC terdiri dari beberapa tahapan, yang terdiri dari 6 tahapan, yakni tahapan analisis sistem, tahapan perancangan sistem, tahapan pembangunan sistem, tahap pengujian sistem, tahapan implementasi, tahap pemeliharaan system dapat dilihat pada Gambar 1.

\subsection{Analisis Sistem}

Analisa sistem yang sedang berjalan setelah dilakukan dengan tahap observasi lapangan dan wawancara dengan petugas perpustakaan, hasilnya adalah proses pendaftaran anggota oleh pengguna umum, peminjaman, pengembalian buku, pengumpulan buku tugas akhir, pengumpulan buku magang, pengajuan surat bebas pustaka diajukan oleh anggota ke staff perpustakaan. Semua proses di tangani oleh pustakawan secara langsung. Keadaan pandemik covid-19 sekarang ini, maka semua kegiatan langsung ditangani oleh petugas menjadi bahaya sendiri dalam penyebaran virus covid-19 yang dapat menyebar dan menular dari manusia ke manusia[8]. Hasil dari analisa dapat dilihat pada gambar 2 .

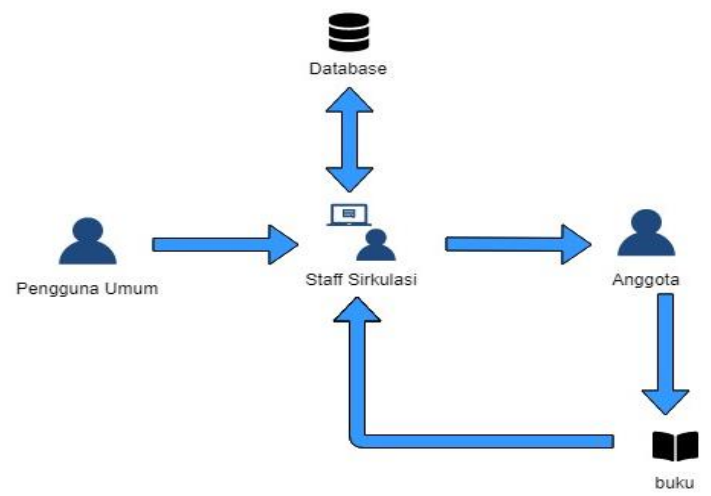

Gambar 2. Analisa Sistem Yang Sedang Berjalan

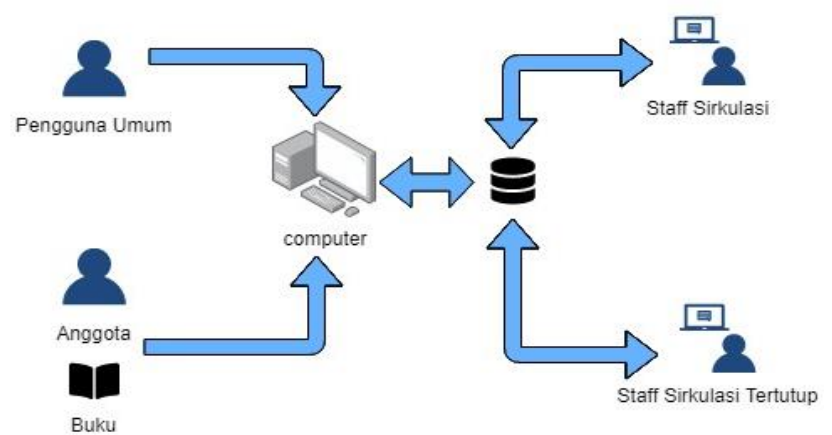

Gambar 3. Analisa Sistem Yang Akan Dikembangkan.

Analisa sistem yang akan dikembangkan merubah proses bisnis yang ada sehingga beberapa proses akan dilakukan secara mandiri dalam upaya mencegah penyebaran covid-19. Analisa system yang akan dikembangkan dapat dilihat pada Gambar 3.

Gap analisis yang ditemukan adalah kondisi saat ini, data yang dikelola baik sirkulasi untuk buku dan buku tugas ahir atau magang dan administrasi akan dilakukan secara langsung oleh staff perpustakaan, dengan banyaknya kegiatan tersebut dan jumlah staff yang sedikit yaitu sebanyak 4 orang dengan perannya masing-masing maka penyelesaian pekerjaan menjadi lebih lama. Peminjaman buku tugas akhir juga akan terhambat karena perpustakaan tutup atau tidak full untuk waktu pelayanan dikarenakan adanya pandemik. 
Pengukuran gap terhadap kualitas dari layanan yang ada perpustakaan berdasarkan persepsi pengguna sangat diperlukan[9]. Kondisi yang diharapkan dengan membangun system yaitu aplikasi yang ada dapat memproses data misalnya peminjaman dan pengembalian buku mandiri, melihat referensi tugas akhir atau magang dalam aplikasi, mengelola administrasi perpustakaan yang dapat diadaptasikan dengan kondisi pandemik yaitu konsep jaga jarak sehingga pelayanan dapat dilakukan secara mandiri.

Pengguna dalam sistem ini yaitu staff sirkulasi dan sirkulasi tertutup, kepala perpustakaan, mahasiswa. Observasi telah dilakukan di unit perpustakaan dengan hasil requirement analysis. Pengguna umum, fungsi yang diperlukan yaitu pendaftaran anggota. Staff Sirkulasi, beberapa fungsi yang diperlukan yaitu fungsi login, surat bebas pustaka, persetujuan buku tugas akhir, persetujuan buku magang, olah jurusan, mou/kerjasama, pelatihan staff, kepala upt, kegiatan perpus, olah ebook, pengunjung online, peminjaman, dan pengembalian.

Staff perpus tertutup, beberapa fungsi yang diperlukan, diantaranya login, peminjaman buku tugas akhir/magang, pengembalian buku tugas akhir/magang, anggota, beberapa fungsi yang diperlukan yaitu login, lihat ebook, olah tugas akhir, olah magang, lihat tugas akhir, lihat magang, peminjaman mandiri, pengembalian mandiri, dan bebas pustaka

\subsection{Rancangan, Pembangunan dan Uji Sistem}

Proses desain dilakukan setelah tahap analisis dengan menterjemahkan proses dan data kedalam desain sistem digitalisasi dan otomatisasi perpustakaan. Proses desain dilakukan dengan menggunakan konsep UML yaitu usecase diagram dan sequence diagram. Usecase Diagram merupakan diagram mendeskripsikan interaksi antara user (pengguna) dengan suatu sistem melalui sebuah alur bagaimana sebuah sistem dipakai[10].

Pada tahap pembangunan sistem, proses yang dilakukan yaitu proses coding dengan menerjemahkan rancangan yang telah dibuat dengan UML yaitu usecase diagram dan class diagram kedalam bahasa pemrograman. Pembangunan system digitalisasi dan otomatisasi administrasi perpustakaan menggunakan bahasa pemrograman yaitu menggunakan bahasa pemrograman PHP dan database menggunakan Mysql.

Tahapan pengujian dengan menggunakan metode blackbox testing dengan tahapan yang dilakukan yaitu proses identifikasi masalah, memilih modul yang akan diuji, mengisikan data uji ke modul yang akan diuji. proses pengujian pada sistem digitalisasi dan aministrasi perpustakaan dilakukan dengan menggunakan metode blackbox testing pendekatan boundary value analysis yang menguji jumlah digit maksimal dan digit minimal untuk mendapatkan nilai yang valid [12] dengan tahapan seperti Gambar 6.

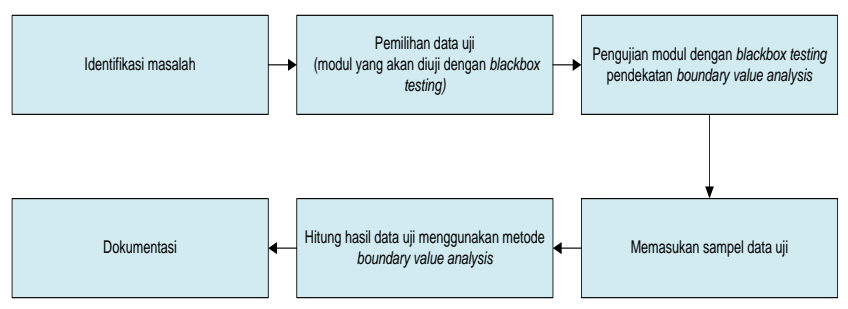

Gambar 6. Tahapan Pengujian Sistem dengan Metode Blackbox Testing

Pengujian dilakukan pada modul pengisian data buku tugas akhir dan magang industri yang dimasukan oleh mahasiswa secara mandiri. Hasil Pengujian memperlihatkan bahwa aplikasi ini mampu dalam menangani data, baik pengisian data normal ataupun data yang tidak normal dengan persentase keberhasilan 91, 67\%.

\section{Hasil dan Pembahasan \\ 3.1 Hasil Rancangan Sistem}

Hasil perancangan Use case diagram sistem digitalisasi dan otomatisasi perpustakaan PNC dapat dilihat pada Gambar 4.

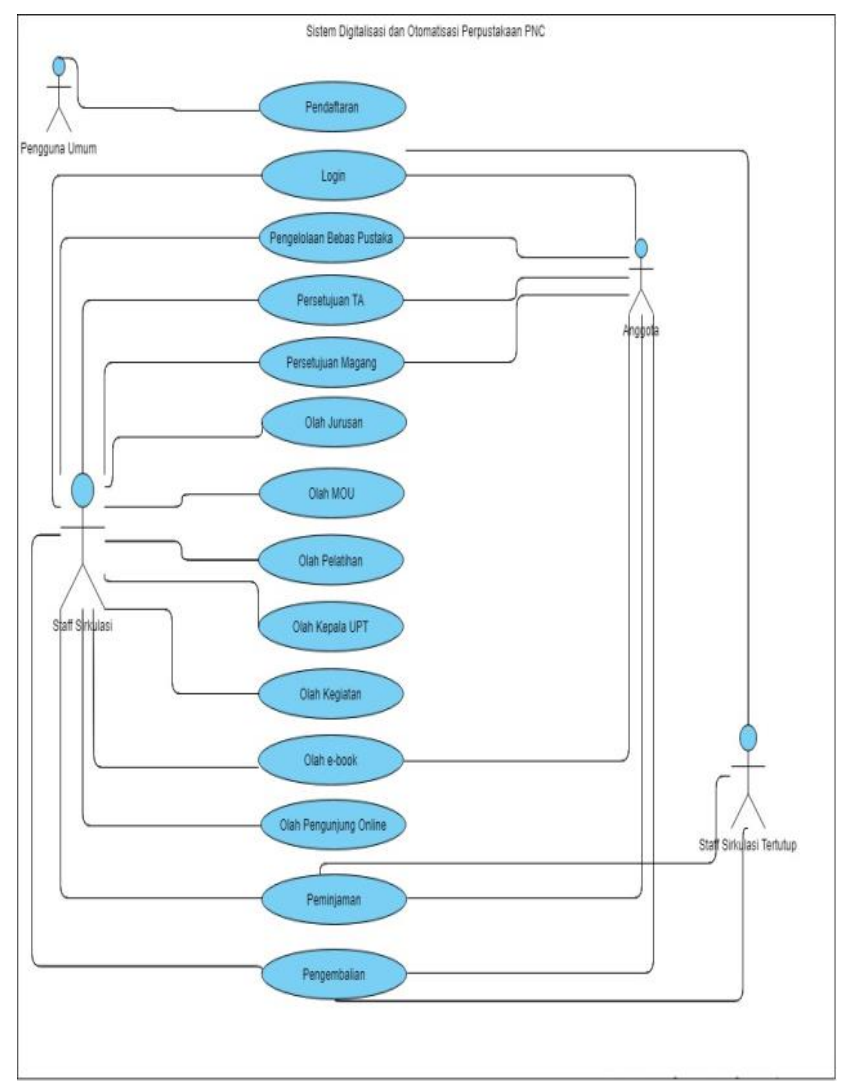

Gambar 4. Usecase Diagram

Class diagram memberikan gambaran secara luas dari suatu sistem atau aplikasi dengan memperlihatkan kelaskelas dan hubungan mereka[11]. Class diagram dapat dilihat pada Gambar 5. 


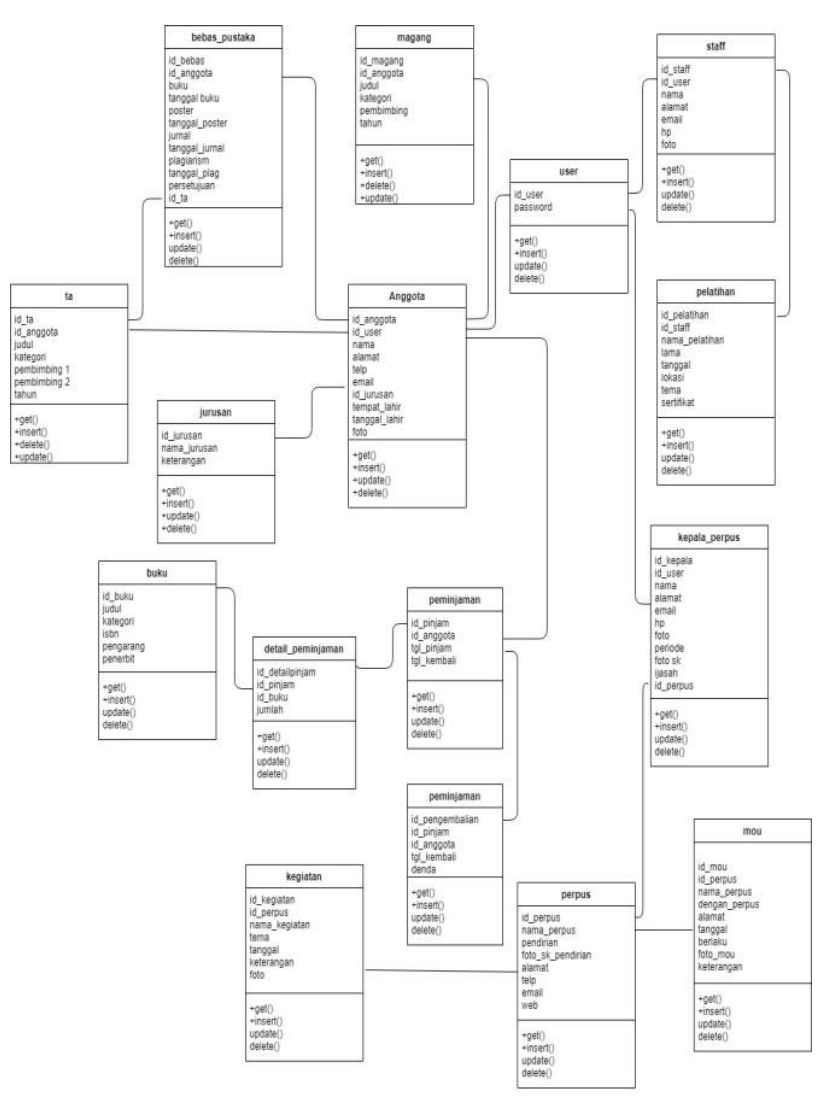

Gambar 5. Class diagram

\subsection{Implementasi Desain Sistem}

Hasil penelitian berupa sistem digitalisasi dan administrasi perpustakaan Politeknik Negeri Cilacap. Tampilan aplikasi penyerahan buku magang atau tugas akhir dilakukan secara mandiri oleh anggota perpustakaan yang merupakan mahasiswa Politeknik Negeri Cilacap. Anggota mengisikan data-data yang dibutuhkan sehingga staff perpustakaan tidak perlu mengisikan kembali. Gambar pengumpulan data tugas akhir dan magang dapat dilihat pada gambar 7. Peminjaman buku oleh anggota akan diproses oleh anggota sendiri dengan komputer yang disediakan untuk memproses peminjaman buku. Tampilan peminjaman buku dibuat sederhana untuk mempermudah dan memperjelas proses peminjaman sehingga keberhasilan peminjaman buku secara mandiri dapat tercapai. Tampilan peminjaman buku secara mandiri dapat dilihat pada gambar 8.

Pada tampilan pengembalian buku akan dilakukan oleh anggota secara mandiri. Buku yang tidak ada denda maka bias diproses pengembaliannya oleh anggota, jika ada denda dalam pengembalian maka anggota harus memprosesnya ke staff perpustakaan. Tampilan pengembalian buku dapat dilihat pada Gambar 9.

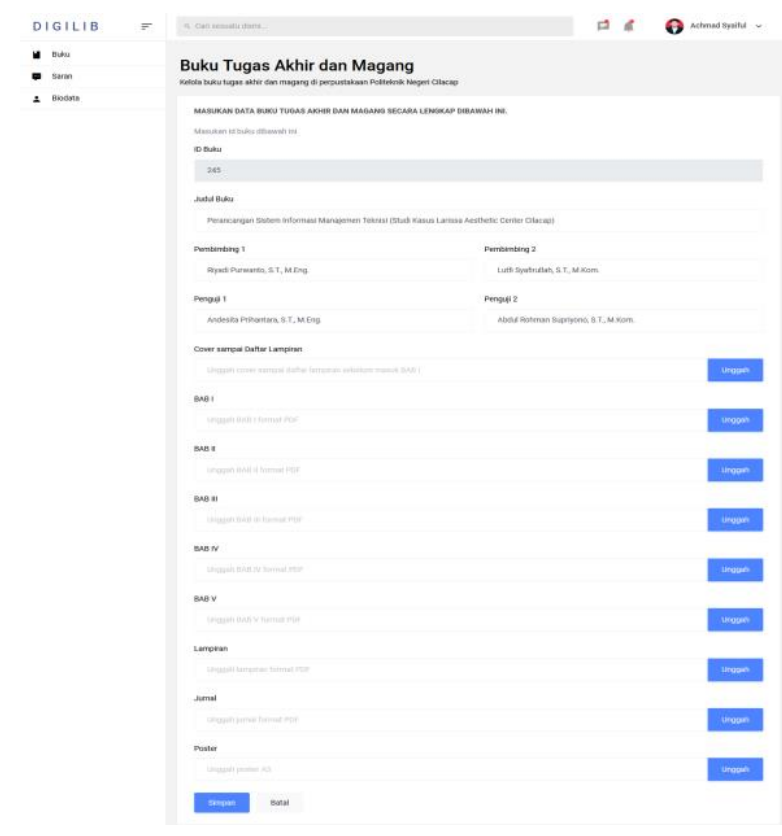

Gambar 7. Tampilan Pengolahan Data Buku Magang dan Tugas Akhir

\section{DIGILIB}

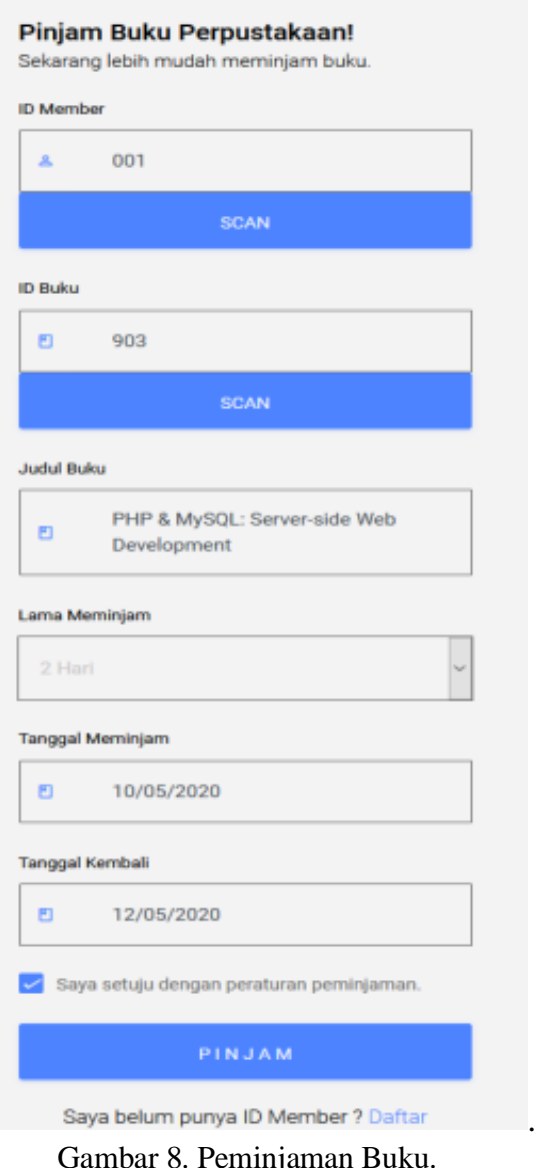

Gambar 8. Peminjaman Buku. 


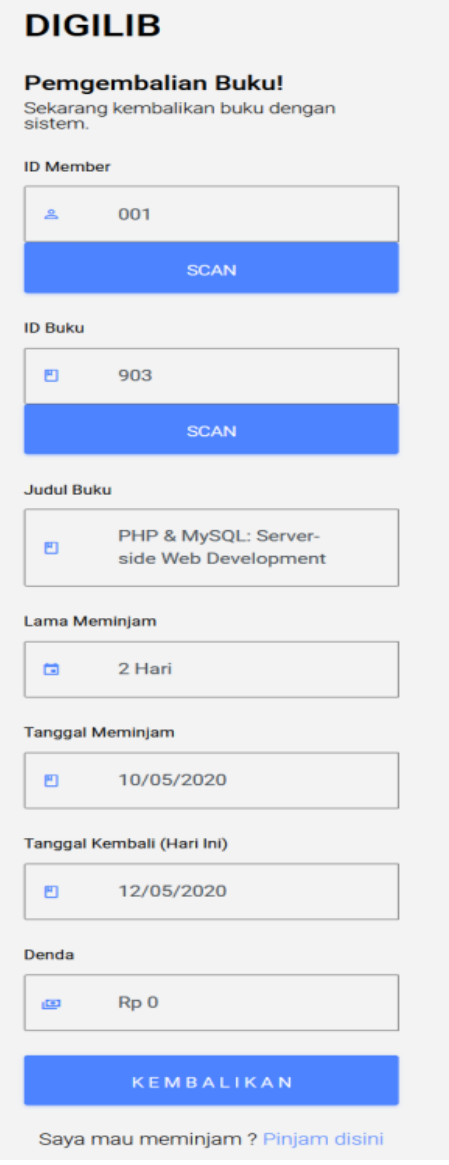

Gambar 9. Tampilan Pengembalian Buku

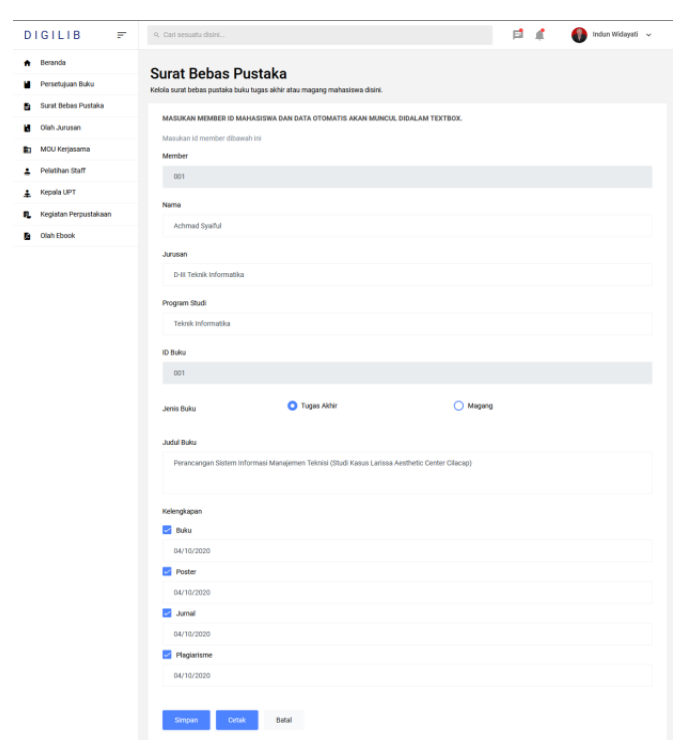

Gambar 10. Tampilan Persetujuan Surat Bebas Pustaka

Proses bebas pustaka sebagai syarat pendaftaran wisuda dapat lebih terdata dengan menggunakan aplikasi. Kelengkapan dicek pada pengajuan bebas pustaka. Tampilan bebas pustaka dapat dilihat pada Gambar 10. Administrasi untuk mengolah data MOU kerjasama dapat dilihat pada Gambar 11, Pengelolaan data pelatihan yang diikuti oleh staff dapat dilihat di Gambar 12, Saran dapat diberikan oleh anggota tampilannya dapat dilihat pada gambar 13 .

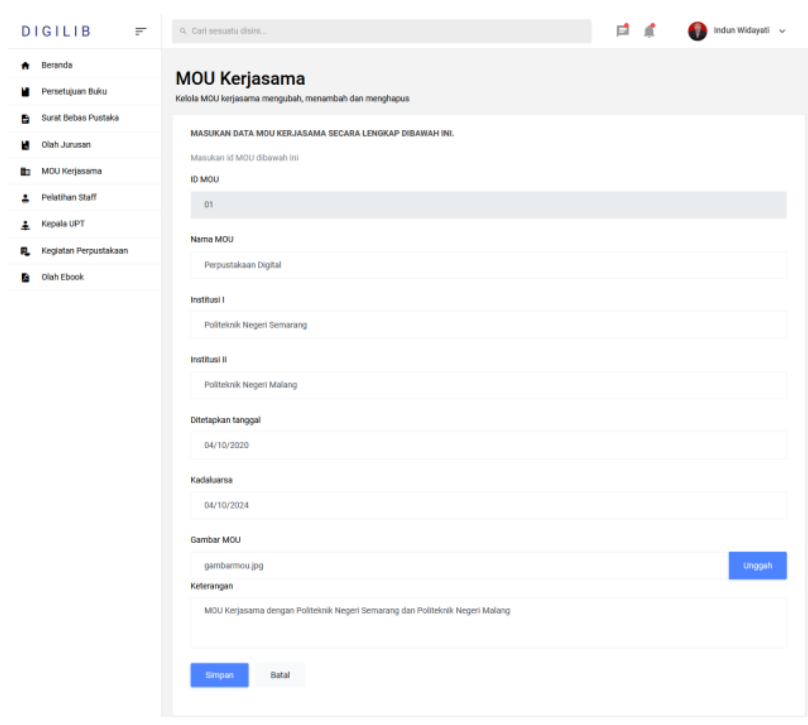

Gambar 11. Tampilan MOU Kerjasama

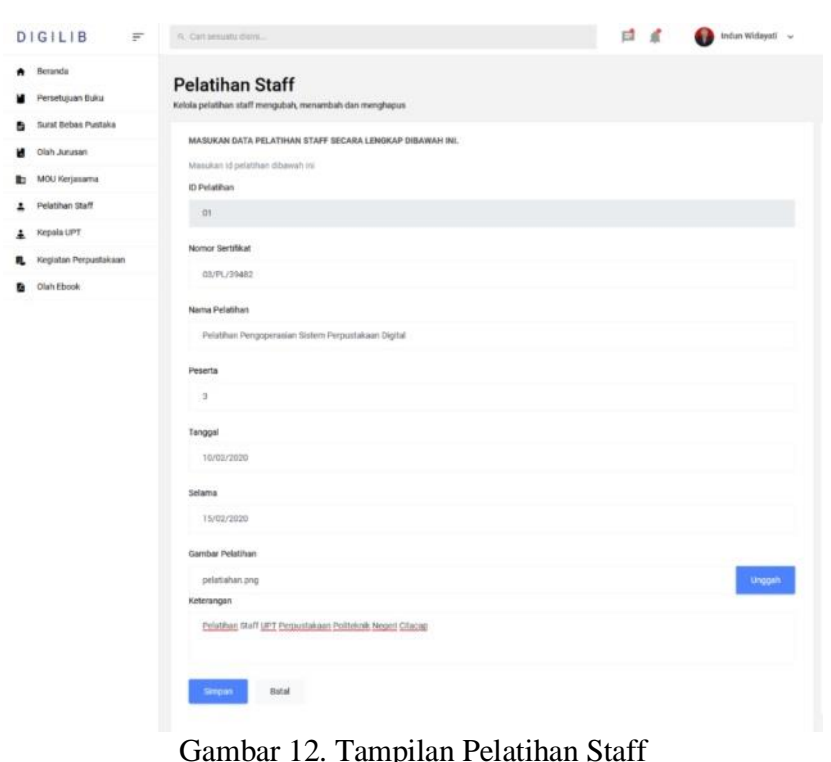

Gambar 12. Tampilan Pelatihan Staff

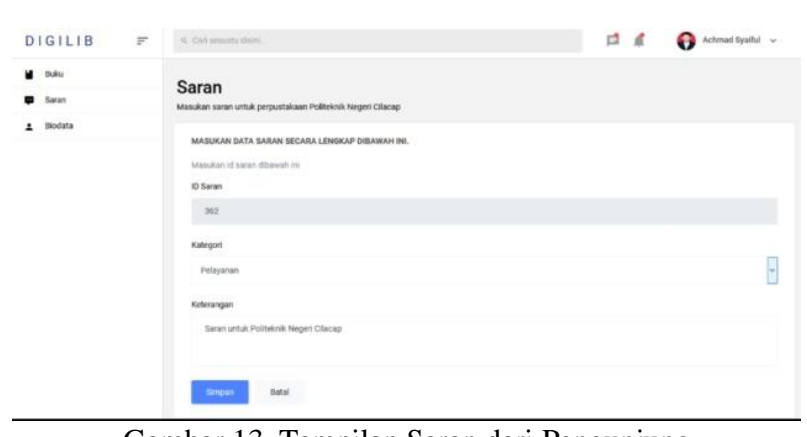

Gambar 13. Tampilan Saran dari Pengunjung

\subsection{Evaluasi system}

Evaluasi Sistem perlu dilakukan untuk menilai manfaat yang didapatkan sehingga dapat mendukung tujuan perpustakaan[13]. Evaluasi system menggunakan 
end user computing satisfaction (EUCS) merupakan metode yang digunakan untuk mengukur tingkat kepuasan dari pengguna sebuah sistem aplikasi dengan melakukan pembandingan antara harapan dan kenyataan dari sebuah aplikasi atau sistem[14] yaitu Perilaku suka (puas) dari pengguna ketika berinteraksi langsung dengan aplikasi yang dibuat untuk mendukung perpustakaan[15]. Pengukuran untuk menentukan kepuasan pengguna dalam system ini dibagi menjadi 5 kategori antara lain Isi (Content), Akurasi (Accuracy), Bentuk (Format), Kemudahan Pengguna (Ease of Use), Ketepatan Waktu (Timeless)

Koresponden unntuk melakukan evaluasi system sebanyak 100 orang, terdiri dari 4 staff perpustakaan dan mahasiswa dari berbagai jurusan di Politeknik Negeri Cilacap. Penyebaran angket untuk mengetahui jawaban dengan kategori Sangat Tidak Setuju (STS), Tidak Setuju (TS), Netral (N), Setuju (S), serta Sangat Setuju (SS). Proses selanjutnya dilakukan analisis menggunakan Metode Likert, seperti pada persamaan (1)

$$
\text { persentase }(\mathrm{P}) \mathrm{P}=\frac{\sum \mathrm{SH}}{\sum S K} X 100 \%
$$

dimana,

$\sum$ SK adalah skor tertinggi tiap item pernyataan $\mathrm{X}$ Jumlah item pernyataan $\mathrm{X}$ Jumlah responden. umlah skor total hasil pengumpulan data variabel $(\mathrm{X})(\mathrm{SH})$

Tabel 2. Hasil Perhitungan metode EUCS

\begin{tabular}{|c|c|c|c|c|}
\hline Kategori & $\sum$ SK & $(\mathbf{X})(\mathbf{S H})$ & $\begin{array}{l}\mathrm{P}= \\
\frac{\sum \mathrm{SH}}{\sum S K} X 100 \%\end{array}$ & Kategori \\
\hline Isi & 1500 & 1210 & $80,66 \%$ & Setuju \\
\hline Akurasi & 1500 & 1100 & $73,3 \%$ & Setuju \\
\hline Bentuk & 2000 & 1600 & $80 \%$ & Setuju \\
\hline Kemudahan & 1500 & 1160 & $77,3 \%$ & Setuju \\
\hline Tepat Waktu & 1000 & 680 & $68 \%$ & Setuju \\
\hline \multicolumn{3}{|c|}{ Rata-rata } & $75,85 \%$ & Setuju \\
\hline
\end{tabular}

Berdasarkan Tabel 2, dapat disimpulkan bahwa sebanyak $75,85 \%$ dari responden sebanyak 100 orang menyatakan setuju sesuai kategori EUCS mengenai sistem perpustakaan digital dan administrasi perpustakaan. Hasil yang ada sebagai salah satu alat ukur yaitu kepuasaan pengguna akhir dari system perpustakaan[16]

\section{Kesimpulan}

Kesimpulan yang dapat diambil dalam penelitian sesuai dengan evaluasi sistem sebanyak 75,85 setuju sesuai dengan kategori EUCS mengenai pelayanan sirkulasi mandiri akan mempermudah peminjaman dan pengembalian buku secara mandiri yang dapat dilakukan oleh mahasiswa. Fasilitas sistem berupa perpustakaan digital meliputi referensi tugas akhir dan magang industri akan mempermudah pencarian referensi tugas akhir oleh pemustaka sehingga dapat dijadikan referensi untuk tugas akhirnya. Sistem juga mempermudah dan data lebih terpusat mengenai administrasi perpustakaan PNC.

\section{Daftar Pustaka}

[1] A. Irawan and A. Nujiullah, "SISTEM INFORMASI PERPUSTAKAAN PADA UNIVERSITAS SERANG RAYA BERBASIS WEB," Protekinfo, vol. 2, no. September, pp. 34-39, 2015.

[2] R. Arista, "Kualitas Pelayanan Perpustakaan Daerah Kabupaten Subang," Din. J. Ilm. Ilmu Adm. Negara, vol. 6, no. 4, pp. 280-288, 2019, [Online]. Available: https://jurnal.unigal.ac.id/index.php/dinamika/article/view/3 098.

[3] W. K. Minsih, Jatin Sri Nandang, "Pengaruh Kualitas Pelayanan Perpustakaan Terhadap Minat Baca Siswa Di Sekolah Dasar," J. Basicedu, vol. 5, no. 3, pp. 1252-1258, 2021.

[4] Aziza Nur Persia and M. . S. . Yuli Rohmiyati , S . Sos ., "Peran Perpustakaan Anak di Rumah Sakit Kanker 'Dharmanis' Jakarta," J. Ilmu Perpust., vol. 2, no. 3, pp. 07, 2013.

[5] Ely Satiyasih Rosali, "Aktifitas Pembelajaran Daring Pada Masa Pandemi Covid -19 Di," Geogr. Sci. Educ. J., vol. 1, no. 1, pp. 21-30, 2020.

[6] O. I. Handarini and S. S. Wulandari, "Pembelajaran Daring Sebagai Upaya Study From Home (SFH) Selama Pandemi Covid 19 Oktafia," J. Pendidik. Adm. Perkantoran, vol. 35, no. 5, pp. 639-643, 2018, doi: 10.1093/fampra/cmy005.

[7] Y. Firmansyah and U. Udi, "Penerapan Metode SDLC Waterfall Dalam Pembuatan Sistem Informasi Akademik Berbasis Web Studi Kasus Pondok Pesantren Al-Habib Sholeh Kabupaten Kubu Raya, Kalimantan Barat," $J$. Teknol. dan Manaj. Inform., vol. 4, no. 1, pp. 184-191, 2018, doi: 10.26905/jtmi.v4i1.1605.

[8] F. Kedokteran and U. Lampung, "Wellness and healthy magazine," vol. 2, no. February, pp. 187-192, 2020.

[9] I. G. Prihanto, "Analisis Kesenjangan Kualitas Layanan Website Lembaga Penerbangan Dan Antariksa Nasional ( Gap Analysis of Website Services Quality in Indonesian National Institute of Aeronautics and Space )," Ber. Dirgant., vol. 19, no. 2, pp. 95-106, 2018.

[10] T. B. Kurniawan, "Perancangan Sistem Aplikasi Pemesanan Makanan Dan Minuman Pada Cafetaria No Caffe Di Tanjung Balai Karimun Menggunakan Bahasa Pemograman," J. TIKAR, vol. 1, no. 2, pp. 192-206, 2020.

[11] desy, "Class Diagram." http://desy.lecturer.pens.ac.id/Workshop Pengembangan Perangkat Lunak/4_Class Diagram.pdf.

[12] S. R. Yulistina, T. Nurmala, R. M. A. T. Supriawan, S. H. I. Juni, and A. Saifudin, "Penerapan Teknik Boundary Value Analysis untuk Pengujian Aplikasi Penjualan Menggunakan Metode Black Box Testing," J. Inform. Univ. Pamulang, vol. 5, no. 2, p. 129, 2020, doi: 10.32493/informatika.v5i2.5366.

[13] A. Khotimah, "Evaluasi Sistem Informasi Manajemen Menggunakan Model HOT-Fit Fasilitas Kesehatan X di Yogyakarta," J. Ilm. Permas J. Ilm. STIKES Kendal, vol. 11, no. 1, pp. 199-206, 2021.

[14] A. Ilias, M. R. Yasoa', M. Z. A. Razak, and R. A. Rahman, "The Study of End-User Computing Satisfaction (EUCS) on Computerised Accounting System (CAS) Among Labuan F.T Private Companies," Sustain. Compet. a Lib. Econ. Role Account., vol. 2, no. 1, pp. 12-35, 2015, doi: 10.5848/csp.1487.00001.

[15] A. S. Restanti, E. Y. Astuti, M. Munjiati, U. Nurwijayanti, and S. Widianingtias, "Analisis End-User Computing Satisfaction pada Online Public Access Catalogue 'Izylib' di Lingkungan Universitas Jenderal Soedirman," Pustabiblia J. Libr. Inf. Sci., vol. 1, no. 2, p. 223, 2018, doi: 10.18326/pustabiblia.v1i2.223-238. 
p-ISSN: 2087-1627, e-ISSN: 2685-9858

[16] M. A. Sugandi and R. M. N. Halim, "Analisis End-User Computing Satisfaction (Eucs) Pada Aplikasi Mobile
Universitas Bina Darma," Sistemasi, vol. 9, no. 1, p. 143, 2020, doi: 10.32520/stmsi.v9i1.625. 